\title{
ASSOCIATION OF HEAT SHOCK PROTEIN 60 WITH NOISE-INDUCED HEARING IMPAIRMENT AND ELECTROCARDIOGRAPHIC ABNORMALITIES AMONG WORKERS OCCUPATIONALLY-EXPOSED TO NOISE
}

\author{
By \\ El-Sherif $\mathrm{GH}^{1}$, Manawil $\mathrm{M}^{1}$ and Diaa $\mathrm{N}^{2}$ \\ ${ }^{I}$ Department of Occupational and Environmental Medicine, ${ }^{2}$ Department of Clinical Pathology, \\ Faculty of Medicine, Cairo University.
}

\begin{abstract}
Introduction: Heat Shock Protein 60 (HSP 60) and other heat shock proteins play an important role in cellular survival under stressful conditions. HSP 60 participates in the course of many cardiovascular diseases. Exposure to severe noise can results in induction of heat shock proteins (HSPs). Aim of Work: to explore a possible association between HSP 60 and both noise-induced hearing loss (NIHL) and electrocardiographic (ECG) abnormalities among workers occupationally exposed to noise. Material and methods: A cross-sectional comparative study was conducted on 35 workers exposed to noise at work and 42 individuals as a control group. Pure-tone audiometry was carried out to all participants. ECG recordings and measurements of HSP 60 levels in serum were also performed to the exposed and the control using enzyme linked immunosorbent assay (ELISA) technique. Results: Statistically significant differences $(\mathrm{P}<0.05)$ were found on comparing exposed workers and control group as regards HSP 60 levels, ECG abnormalities and NIHL in low and high frequencies. A comparison between HSP 60 levels with ECG abnormality among the exposed workers revealed a statistically non-significant difference $(\mathrm{P}<0.05)$. Meanwhile, statistically highly significant differences were found on comparing HSP 60 levels in the normal hearing exposed workers with each of the NIHL subgroups as regards low frequency hearing loss $(\mathrm{P}<0.01)$ and high frequency hearing loss $(\mathrm{P}<0.001)$. Conclusion: The study revealed an association between serum HSP 60 levels and NIHL, but no association was found between serum HSP60 and ECG abnormalities among workers occupationally exposed to noise.
\end{abstract}

Keywords: Noise, Heat Shock Protein 60, Hearing loss and ECG. 


\section{Introduction}

Noise has become a common feature in the environment during the last years. Health hazards due to noise exposure accumulate over the long life spans of people. Noise-induced hearing loss has become a world-wide problem (Christie and Eberl, 2014).

There are many sources of noise in the Egyptian environment with traffic and different sized industries as important sources (El Samra, 2016). Health effects of noise include hearing impairment and disturbance of physiological functions as cardiovascular system effects.

Permanent vascular changes and alterations in the heart muscle in animals have been observed due to chronic exposure to high intensity noise which indicates an increased risk of cardiovascular mortality. Epidemiological studies carried out in the occupational field have shown that employees working in high noise environments are at a higher risk for high blood pressure and myocardial infarction (Babisch, 2011).

Heat shock proteins (HSPs) are a class of functionally related proteins whose expression is increased when cells are exposed to elevated temperatures or other stresses (Hassan et al., 2010). Diverse cellular and environmental stresses can activate the heat shock response, an evolutionarily conserved mechanism to protect proteins from denaturation (Gong et al., 2012).

HSPs protect from hearing loss by conditioning the ear to withstand consequences of severe noise exposure (Altschuler et al., 2002). Some HSPs play an important role in protecting cardiac cells against ischemic injury, and antibodies against these HSPs (anti-HSPs) are associated with the development and prognosis of atherogenesis, coronary heart disease and hypertension (Yuan et al., 2005 and Mandal et al., 2004). Enhanced levels of anti-HSPs have been detectable in individuals with some cardiovascular diseases, such as atherosclerosis, coronary heart disease and borderline hypertension.

HSP60 and other heat shock proteins are essential for cellular survival under toxic or stressful conditions. HSP60 is mainly found in the mitochondria of cells (Rossi et al., 2002), but it can also 
be present at the cell surface (Bason et al., 2003). The heat shock response is a homeostatic mechanism that protects a cell from damage by upregulating the expression of genes that code for HSP60 (Vargas-Parada and Solis, 2001).

HSP60 is typically cytoprotective, but a number of stress conditions determine its conversion to a potentially toxic molecule for cells and tissues. HSP60 plays variable roles, most likely depending on the existing conditions at the cell or tissue level. HSP60 may play an antiatherogenic or a proatherogenic role, depending on currently unknown mechanisms (Rizzo et al., 2011).

Ho et al. (2012) found that serum HSP60 does not provide clinical significance as regards hearing outcome of sudden sensorineural hearing loss, but no research was found to be interested in associating HSP60 with NIHL.

\section{Aim of work}

The aim of this study is to explore a possible association between HSP60 and both noise-induced hearing loss (NIHL) and ECG abnormality among workers occupationally-exposed to noise.

\section{Materials and methods}

- Study design: cross-sectional comparing study.

- Place and duration of the study: The study was carried out in the Occupational Medicine clinic of El Nasr Hospital for Health Insurance in Helwan, Cairo, during the period from January to December 2015.

- Study subjects: The exposed group included 35 workers whose age ranged from 27- 60 years, who came to the clinic for periodic examination and who met the inclusion criteria and agreed to participate in the study.

- Inclusion criteria of the exposed group were exposure to noise of more than $85 \mathrm{~dB}$ at the workplace -according to the periodic measurements at the work environment - for at least 5 years. They were occupationally-exposed to noise for 5 - 40 years. They were not occupationally-exposed to any other physical or chemical stressors.

- Exclusion criteria included the presence of ear diseases or hearing affection due to congenital 
anomalies, infections, tumours, ototoxic drugs or trauma. In addition to that, history of any manifestations of infection within one month before the examination was considered as an exclusion criterion as it may be a stressor (Yuan et al., 2005).

- A control group of 42 male individuals were randomly selected as to be matched with the exposed group as regards age, gender, and special habits of medical importance. Their ages ranged from 23 - 61 years. They were patients coming to the Occupational Medicine outpatient clinic at Kasr Alainy Hospital. Most of them were complaining of gastrointestinal manifestations as gastritis or colonic problems or came for follow up. None of them was feverish or showing manifestations of acute infection that can be considered as a source of stress. They all satisfied the exclusion criteria.

- Study methods:

- Questionnaire

Pre designed questionnaire was prepared including personal, occupational, present, past and family history.

\section{- Clinical examination}

Full clinical examination was carried out to the studied groups.

\section{- Audiometry}

Pure-tone audiometry was done to the studied group using a DANPLEX portable diagnostic audiometer AS 67. It was performed for both ears at frequencies $(500,1000,2000,4000$, 6000 and $8000 \mathrm{~Hz}$ ). Hearing threshold worse than $25 \mathrm{~dB}$ in either ear was considered as hearing impairment. Hearing impairment can either be in the low-frequency range (500 -2000 $\mathrm{Hz}$ ) or in the high-frequency range $(4000-8000 \mathrm{~Hz})$. Severity of hearing impairment was further categorized by the extent of displacement of the hearing threshold using the World Health Organization (WHO) grading: normal $(<25 \mathrm{~dB})$; slight $(26-40 \mathrm{~dB})$; moderate (41-60 dB) and severe (61$80 \mathrm{~dB})$.

\section{- Electrocardiography (ECG)}

A portable ECG device was used to record ECG for the exposed and control 
groups. (CONTEC medical systems co., model: ECG-100G, Hebeprovina, Quinhuangdao, Hebei Province, China).

\section{- Laboratory Investigations}

A blood sample of $3 \mathrm{ml}$ was drawn through venipuncture of the arm using a sterile plastic syringe. Blood was centrifuged for separation of serum to determine the level of heat shock protein 60 (HSP60) for the studied groups by enzyme linked immunosorbent assay (ELISA) using Human HSP60 ELISA Kit (AssayMaxTM) provided by Assaypro LLC (www.assaypro.com). This kit is designed for detection of human HSP60 in plasma, serum, cell culture lysates and tissue samples. This assay employs a quantitative sandwich enzyme immunoassay technique that measures human HSP60 in less than 5 hours. Serum HSP60 is measured in ng/ $\mathrm{ml}$.

\section{Consent}

An informed verbal consent was taken from subjects who agreed to participate in the study before the start of work with assurance of confidentiality and anonymity of data.

\section{Ethical approval}

Approval of the administrative authority of the hospital was obtained. The study protocol was approved by the Ethical Committee of the Department of Occupational and Environmental Medicine, Faculty of Medicine, Cairo University.

\section{Data management}

Data analysis was done using the statistical analysis software SPSS version 20 package. The student' t-test and chi-square test were used for comparisons between various continuous and categorical variables, respectively. Mann-Whitney test was used for comparison of non-parametric data, while kruskall-Wallis one-way ANOVA was used for comparison of more than two non-parametric data. Spearman's rho test was applied on non- parametric data to assess the correlation. Statistical differences were based on the significance level of $\mathrm{P}<$ 0.05 . 


\section{Results}

Table 1: Comparison between exposed and control groups as regards age, smoking habit, low and high frequency hearing impairment, ECG abnormalities, and HSP60 .

\begin{tabular}{|c|c|c|c|c|c|}
\hline & & Exposed & Control & & p-value \\
\hline \multicolumn{2}{|l|}{ Age $($ Mean \pm SD) } & $50.34 \pm 8.28$ & $47.1 \pm 10.19$ & $\begin{array}{c}1.54 \S \\
(\mathrm{t})\end{array}$ & 0.127 \\
\hline & & No. & No. & & \\
\hline Smoking & $\begin{array}{l}\text { Smokers } \\
\text { Non-smokers }\end{array}$ & $\begin{array}{l}9(25.7 \%) \\
26(74.3 \%)\end{array}$ & $\begin{array}{l}10(23.8 \%) \\
32(76.2 \%)\end{array}$ & $\begin{array}{c}0.04 \# \\
\left(\chi^{2}\right)\end{array}$ & 0.847 \\
\hline $\begin{array}{l}\text { Low freq hearing } \\
\text { threshold }\end{array}$ & $\begin{array}{l}\text { NIHL } \\
\text { normal }\end{array}$ & $\begin{array}{l}18(51.4 \%) \\
17(48.6 \%)\end{array}$ & $\begin{array}{c}9(21.4 \%) \\
33(78.6 \%)\end{array}$ & $\begin{array}{c}7.55 \# \\
\left(\chi^{2}\right)\end{array}$ & $0.006 *$ \\
\hline $\begin{array}{l}\text { High freq hearing } \\
\text { threshold }\end{array}$ & $\begin{array}{l}\text { NIHL } \\
\text { Normal }\end{array}$ & $\begin{array}{l}22(62.9 \%) \\
13(37.1 \%)\end{array}$ & $\begin{array}{c}6(14.3 \%) \\
36(85.7 \%)\end{array}$ & $\begin{array}{c}19.46 \# \\
\left(\chi^{2}\right)\end{array}$ & $<0.001 * *$ \\
\hline ECG & $\begin{array}{l}\text { Abnormal } \\
\text { Normal }\end{array}$ & $\begin{array}{l}12(34.3 \%) \\
23(65.7 \%)\end{array}$ & $\begin{array}{c}6(14.3 \%) \\
36(85.7 \%) \\
\end{array}$ & $\begin{array}{l}4.26 \# \\
\left(\chi^{2}\right) \\
\end{array}$ & $0.039 *$ \\
\hline Serum HSP $60(\mathrm{ng} / \mathrm{ml})$ & Mean \pm SD & $7.25 \pm 12.77$ & $0.8 \pm 0.03$ & $\begin{array}{c}-7.46 \wedge \\
(\mathrm{Z})\end{array}$ & $<0.001 * *$ \\
\hline
\end{tabular}

$\S$ : Independent samples student's t- test \#: Crosstab Chi-square $\quad \wedge$ : Mann-Whitney U test

\section{*: Significant}

**: Highly significant

Table (1) shows that the workers occupationally-exposed to noise are matched with the control group as regards age and smoking habit showing no statistically significant difference. On the other hand, the exposed and control groups showed statistically significant differences as regards NIHL in low and high frequencies, ECG abnormalities, and serum heat shock protein 60 (HSP60) levels. 
Table 2: Correlation between both age and duration of exposure with HSP60 among the exposed workers and comparison between workers with NIHL and those with normal hearing as regards age and duration of exposure.

\begin{tabular}{|c|c|c|c|c|c|c|c|c|}
\hline \multirow{4}{*}{$\begin{array}{l}\text { HSP } 60 \text { (ng/ } \\
\text { ml) }\end{array}$} & \multicolumn{4}{|c|}{ Age (years) } & \multicolumn{4}{|c|}{ Duration of exposure (years) } \\
\hline & \multicolumn{3}{|c|}{$\mathbf{r}$} & p-value & \multicolumn{3}{|c|}{$\mathbf{r}$} & p-value \\
\hline & \multicolumn{3}{|c|}{$0.38 \#$} & $0.026^{*}$ & \multicolumn{3}{|c|}{$0.25 \#$} & 0.15 \\
\hline & $\begin{array}{c}\text { NIHL } \\
\text { workers }\end{array}$ & $\begin{array}{l}\text { Normal } \\
\text { hearing }\end{array}$ & t-test ${ }^{\S}$ & p-value & $\begin{array}{c}\text { NIHL } \\
\text { workers }\end{array}$ & $\begin{array}{l}\text { Normal } \\
\text { hearing }\end{array}$ & t-test ${ }^{\S}$ & p-value \\
\hline $\begin{array}{l}\text { Low } \\
\text { frequency } \\
\text { hearing } \\
\text { impairment }\end{array}$ & $\begin{array}{c}52.89 \pm 5.47 \\
(\mathrm{No}=18)\end{array}$ & $\mid \begin{array}{c}47.65 \pm 9.95 \\
(\mathrm{No}=17)\end{array}$ & 1.92 & 0.067 & $\begin{array}{c}19.39 \pm 6.49 \\
(\mathrm{No}=18)\end{array}$ & $\begin{array}{c}17.53 \pm 11.63 \\
(\mathrm{No}=17)\end{array}$ & -0.58 & 0.56 \\
\hline $\begin{array}{l}\text { High } \\
\text { frequency } \\
\text { hearing } \\
\text { impairment }\end{array}$ & $\begin{array}{c}51.18 \pm 7.3 \\
(\mathrm{No}=22)\end{array}$ & $\begin{array}{c}48.92 \pm 9.88 \\
(\mathrm{No}=13)\end{array}$ & 0.72 & 0.48 & $\begin{array}{c}19.14 \pm 8.75 \\
(\mathrm{No}=22)\end{array}$ & $\begin{array}{c}17.38 \pm 10.32 \\
(\mathrm{No}=13)\end{array}$ & -0.53 & 0.61 \\
\hline
\end{tabular}

\#: Spearman's rho correlation

$\S:$ student's t test

*: Significant

Table (2) shows a statistically significant positive correlation between HSP60 and age of the exposed workers. At the same time, there is a positive statistically non-significant correlation between HSP60 levels and the duration of exposure to noise.

As regards NIHL, a statistically non-significant difference $(\mathrm{P}>0.05)$ was found between the age of workers with NIHL and those with normal hearing as regards low and high frequency hearing impairment. Meanwhile, a statistically nonsignificant difference $(\mathrm{P}>0.05)$ was encountered between duration of exposure to noise among workers with NIHL and those with normal hearing as regards low and high frequency hearing impairment. 
Table 3: Comparison of HSP60 values between exposed workers with normal hearing and those with low and high frequency NIHL and also between those with normal and abnormal findings in ECG among exposed workers $(\mathrm{No}=35)$.

\begin{tabular}{|c|c|c|c|c|}
\hline & & $\begin{array}{c}\text { Serum HSP60 }(\mathrm{ng} / \mathrm{ml}) \\
(\text { Mean } \pm \text { SD })\end{array}$ & $\mathbf{Z} \#$ & p-value \\
\hline \multirow{2}{*}{$\begin{array}{l}\text { Low frequency } \\
\text { hearing }\end{array}$} & Normal $($ No $=17)$ & $2.26 \pm 2.36$ & \multirow{2}{*}{-3.1} & \multirow{2}{*}{$0.002 *$} \\
\hline & NIHL (No =18 ) & $11.95 \pm 16.51$ & & \\
\hline \multirow{2}{*}{$\begin{array}{l}\text { High frequency } \\
\text { hearing }\end{array}$} & Normal $($ No $=12)$ & $1.98 \pm 1.23$ & \multirow{2}{*}{-1.8} & \multirow{2}{*}{0.07} \\
\hline & NIHL (No = 23) & $10 \pm 15.1$ & & \\
\hline \multirow{2}{*}{ ECG } & Normal (No =23) & $6.37 \pm 9.82$ & \multirow{2}{*}{-0.45} & \multirow{2}{*}{0.65} \\
\hline & Abnormal (No =12 ) & $8.93 \pm 17.5$ & & \\
\hline
\end{tabular}

\#: independent samples Mann-Whitney $\mathrm{U}$ test

*: Significant

Table (3) shows a statistically significant difference when comparing the levels of HSP60 among the exposed workers with normal hearing and those with low frequency NIHL $(\mathrm{P}<0.05)$, but a statistically non-significant difference was found at high frequency $(\mathrm{P}>0.05)$. The table also shows a statistically non-significant difference between HSP60 levels among exposed workers with normal ECG compared with those with abnormal findings. 
Table 4: Comparison of distribution of serum HSP60 levels among the exposed workers with different degrees of hearing impairment.

\begin{tabular}{|c|c|c|c|c|c|c|c|}
\hline \multicolumn{2}{|c|}{$\begin{array}{c}\text { Low frequency } \\
\text { hearing impairment }\end{array}$} & $\begin{array}{c}\text { Serum HSP60 } \\
(\mathrm{ng} / \mathrm{ml}) \\
(\text { Mean } \pm \text { SD })\end{array}$ & p-value \# & \multicolumn{2}{|c|}{$\begin{array}{c}\text { High frequency } \\
\text { hearing impairment }\end{array}$} & $\begin{array}{c}\text { Serum HSP } \\
60(\mathrm{ng} / \mathrm{ml}) \\
(\mathrm{Mean} \pm \mathrm{SD})\end{array}$ & p-value \# \\
\hline \multicolumn{2}{|c|}{ Normal $(\mathrm{No}=17)$} & $2.26 \pm 2.36$ & \multirow[t]{4}{*}{$<0.001 * *$} & \multicolumn{2}{|c|}{ Normal(No=12) } & $1.98 \pm 1.23$ & \multirow[t]{4}{*}{$<0.001 * *$} \\
\hline \multirow{4}{*}{ 曼 } & Mild (No=6) & $3.27 \pm 3.46$ & & \multirow{4}{*}{ 晋 } & Mild(No=6) & $1.23 \pm 0.18$ & \\
\hline & Moderate $(\mathrm{No}=10)$ & $9.4 \pm 9.24$ & & & Moderate $($ No $=6)$ & $4.43 \pm 4.11$ & \\
\hline & Severe $\left(\mathrm{No}_{0}=2\right)$ & $50.75 \pm 16.62$ & & & Severe $\left(\mathrm{No}_{0}=11\right)$ & $17.81 \pm 19.01$ & \\
\hline & Total $($ No=18) & $11.95 \pm 16.51$ & & & Total $(\mathrm{No}=23)$ & $10 \pm 15.1$ & \\
\hline \multicolumn{2}{|c|}{ Total $\left(\mathrm{No}_{0}=35\right)$} & $7.25 \pm 12.77$ & & & & $7.25 \pm 12.77$ & \\
\hline
\end{tabular}

\#: Kruskall-Wallis one-way ANOVA

**: Highly significant

Table (4) shows a highly statistically significant differences on comparing HSP60 levels among the exposed group showing normal hearing with those showing different degrees of hearing impairment as regards low frequency hearing impairment $(\mathrm{P}<0.001)$ and high frequency hearing impairment $(\mathrm{P}<0.001)$.

Table 5: Frequency distribution of ECG abnormalities among exposed workers and comparison of HSP60 mean levels among the subgroups.

\begin{tabular}{|l|l|c|c|c|c|}
\hline ECG & & No & $\%$ & $\begin{array}{c}\text { HSP 60 (ng/ml) } \\
(\text { Mean } \pm \text { SD) }\end{array}$ & p-value \# \\
\hline \multirow{2}{*}{\begin{tabular}{l} 
Normal \\
\multirow{2}{*}{$\begin{array}{l}\text { ECG } \\
\text { abnormalities }\end{array}$}
\end{tabular}} & Lt. ventricular hypertrophy & 2 & 5.7 & $39.45 \pm 32.6$ & \multirow{2}{*}{0.145} \\
\cline { 2 - 5 } & Ischemic changes & 5 & 14.3 & $3.76 \pm 3.8$ & \\
\cline { 2 - 5 } & Conductive abnormalities & 5 & 14.3 & $1.88 \pm 0.72$ & \\
\cline { 2 - 6 } & Total & 12 & 34.3 & $8.93 \pm 17.5$ & \\
\hline \multicolumn{2}{|l|}{ Total } & 35 & 100 & $7.25 \pm 12.77$ & \\
\hline
\end{tabular}

\#: kruskall-Wallis one-way ANOVA

Table (5) shows that the comparison between HSP60 levels among the exposed workers with normal ECG and each group of ECG abnormality revealed a statistically non-significant difference $(\mathrm{P}>0.05)$. 


\section{Discussion}

HSPs-chaperones constitute a physiological system, now called chaperoning system that plays a crucial role in maintaining cell and tissue homeostasis (Macario et al., 2010). Studies have suggested that HSP60 plays a key role in preventing apoptosis in the cytoplasm. Despite the marked differences between the cytoplasmic and mitochondrial forms of HSP60, experimental analysis has shown that the cell is quickly capable of moving cytoplasmic HSP60 into the mitochondria if environmental conditions demand a higher presence of mitochondrial HSP60 (Itoh et al., 2002).

This work aims to explore a possible association between HSP60 and both noise-induced hearing loss (NIHL) and ECG abnormalities among workers occupationally exposed to noise.

In the present study, workers occupationally exposed to noise were matched with the control group as regards age and smoking habit (Table $1)$.
This study found statistically significant differences among those with hearing impairment in comparison to those with normal hearing at both low and high frequencies among noiseexposed workers compared to the control group (Table 1). Noise-induced hearing impairment begins to appear in the frequency range of $3000-6000 \mathrm{~Hz}$ with highest effect at $4000 \mathrm{~Hz}$ without speech hearing affection. But later on, with continuous noise exposure, impairment extends to low frequencies $(2000 \mathrm{~Hz})$ with speech hearing affection (Berglund et al., 1999).

The current study showed a statistically significant difference of ECG abnormality among noise-exposed workers in comparison with the control group (Table 1). Prolonged exposure to high intensity noise at work causes biochemical changes which make the workers prone to cardiovascular pathology (Osiris et al., 2014). Babisch, 2011 declared that noise affects cardiovascular health. Workers exposed to high occupational noise should be considered at higher overall risk of ischemic heart disease (Dzhambov and Dimitrova, 2016). 
Our study showed a statistically highly significant difference between HSP60 levels among noise-exposed workers compared to the control group (Table 1). The up regulation of HSP60 production allows for the maintenance of other cellular processes occurring in the cell, especially during stressful times (Calabrese et al., 2007).

The effects of age and duration of exposure to noise on NIHL and serum levels of HSP60 among the exposed group were studied in (Table 2). There were no statistically significant differences $(\mathrm{P}>0.05)$ between workers with NIHL and those with normal hearing at low and high frequency with regard to age and duration of exposure. Ferrite and Santana (2005) found that age and occupational noise exposures were separately positively associated with hearing impairment among workers at a metal processing factory. However, Toppila et al. (2001) evaluated the effect of noise, age and confounders as smoking habits, serum cholesterol, blood pressure and use of analgesics in NIHL. They stated that the confounders were considered as significant sources of hearing impairment in younger and elderly subjects and that noise exposure was masked by these confounders in the development of hearing impairment. The current findings may be attributed to the possible presence of these confounders among the exposed group. In our work, the current finding of non- statistically significant difference between age and NIHL weakens the effect of age on hearing impairement among the exposed group.

The current study showed a statistically significant positive correlation between HSP60 and age of the exposed workers and at the same time, there was a statistically nonsignificant correlation between HSP60 levels and the duration of exposure to noise (Table 2). Rea et al.(2001) reported that HSP60 can be detected in healthy subjects with age range of 20-96 years and a progressive decrease in HSP60 levels was detected with increasing age and they mentioned that this decrease with age did not appear to be related to anti-heat shock protein antibody status. At the same time, Macario et al. (2010) stated that the levels and functional quality of intracellular HSPs, as a rule, decrease with age but their over 
expression mostly occurs as a response to various stressors ( as noise), resulting in their intracellular accumulation.

HSPs can be induced by severe noise exposure (Yang et al., 2006). In the current study (Table 3), a statistically significant difference was found when comparing HSP60 levels among the exposed workers with normal hearing and those with NIHL at low frequencies, but a statistically nonsignificant difference was found at high frequencies. The exposed group with NIHL was further divided, according to the severity of hearing impairment, into subgroups mild, moderate and severe hearing impairment. Serum HSP60 levels were compared among these subgroups and the exposed group with normal hearing as regards low frequency and high frequency hearing impairment. Statistically highly significant differences were found on comparing HSP60 levels among the exposed group with normal hearing and those with different degrees of hearing impairment at low frequency $(\mathrm{P}<0.01)$ and high frequency hearing impairment $(\mathrm{P}<0.001)$ (Table 4). No researchers studied the association between HSP60 and NIHL were found to compare our work with them. A study conducted by Ho et al. (2012) was the first work that investigated the serum levels of HSP60 in sudden sensorineural hearing loss (SSNHL) patients as measured by ELISA test. The results revealed no statistically significant difference between HSP60 levels in SSNHL patients and the normal controls with mean \pm SD $(14.64 \pm 52.28),(10.29 \pm$ 21.40) $\mathrm{ng} / \mathrm{ml}$ for patients and controls respectively. So, they concluded that serum HSP60 cannot provide clinical significance in patients with SSNHL. It is the only study that measured HSP60 itself and relate it to sensorineural hearing loss. Yang et al. (2004) found that the prevalence of positive antiHSP60 (not HSP60) in workers with moderate low-frequency NIHL was significantly higher than in normal workers $(\mathrm{P}<0.01)$.

HSP60 is considered as a biomarker to be applied in diagnosis, prognosis and treatment response, as well as for prevention and treatment of cardiovascular diseases (Rizzo et al., 2011). Our study showed that workers with ECG abnormalities represented 
$34.3 \%$ of the total number of the exposed group. The abnormalities recorded among the exposed workers included left ventricular hypertrophy, ischemic changes and conductive abnormalities (Table 3). Our study revealed a statistically non-significant difference between HSP60 levels among both groups of exposed workers with normal and abnormal ECG findings. Moreover, a comparison between HSP60 levels among the exposed workers with normal ECG and each group of ECG abnormality revealed statistically nonsignificant differences (Table 5). A large case-control study was conducted by Zhang et al. (2008) on 1003 individuals with coronary heart disease with the same number as a control group. They found that elevated plasma HSP60 was strongly positively correlated with an increased risk for coronary heart disease and provided the first evidence that HSP60 and anti- HSP60 antibody levels combined to increase the risk of coronary heart disease. This positive correlation was not found in our work which can be attributed to the large number of participants in that study (1003 exposed) compared to our work (35 exposed). In the previous study, they also conducted a prospective study on cases diagnosed as acute myocardial infarction based on characteristic chest pain, ECG changes and biochemical markers elevation and found that HSP60 was released rapidly after development of acute myocardial infarction.

Huilin et al. (2004) stated that antiHSP60 (not HSP60) may be a risk factor for abnormal ECG among the workers exposed to noise. Another study which was conducted on automobile workers exposed to noise and concluded that anti-HSP60 (not HSP60) was associated with ECG abnormalities; sinus arrhythmia, chronic myocardial ischemia, and ectopic rhythm. So, there might be an etiological link between the presence of anti-HSP60 and ECG abnormalities (Yuan et al., 2005). Lewthwaite et al. (2002) assessed the plasma HSP60 among British civil servants and its relation to physiological and psychosocial stress. They stated that HSP60 can be used as a marker linked to susceptibility to coronary heart disease. Also ShamaeiTousi et al. (2007) declared that plasma HSP60 is likely to be related to genetic, biological and psychosocial risk factors for coronary artery disease. 


\section{Conclusion}

\section{The study revealed an association} between serum HSP60 levels and NIHL, but no association was found between serum HSP60 and ECG abnormalities.

\section{References}

1. Altschuler R, Fairfield D, Cho Y, Leonova E, Benjamin IJ et al. (2002): Stress pathways in the rat cochlea and potential for protection from acquired deafness. Audio Neuro otol; 7: 152-6.

2. Babisch W (2011): Cardiovascular effects of noise. Noise Health; 13: 201-4.

3. Bason C, Corrocher R, Lunardi C, Puccetti P, Olivieri $O$ et al. (2003): Interaction of antibodies against cytomegalovirus with heat-shock protein 60 in pathogenesis of atherosclerosis. Lancet; 362: 1961-77.

4. Berglund B, Lindvall T and Scwela DH (1999): Guidelines for community noise. WHO- expert task -force meeting. London U.K.

5. Calabrese V, Mancuso C, Ravagna A, Perluigi M, Cini C et al. (2007): In vivo induction of heat shock proteins in the substantia nigra following L-DOPA administration is associated with increased activity of mitochondrial complex I and nitrosative stress in rats: regulation by glutathione redox state. J Neurochem; 101: 709-17.

6. Christie KW and Eberl DF (2014): Noise- induced hearing loss: new animal models. Curr Opin Otolaryngol Head Neck Surg; 22(5): 374-83.

7. Dzhambov AM and Dimitrova DD (2016): Occupational noise and ischemic heart disease: a systematic review. Noise Health; 18(83): 167-77.

8. El Samra G (2016): Community noise in Greater Cairo. Egyptian Journal of Occupational Medicine; 40(2): 267-85.

9. Ferrite S and Santana V (2005): Joint effects of smoking, noise exposure and age on hearing loss. Occup Med; 55: 48-53.
10. Gong TW, Fairfield DA, Fullarton L, Dolan DF, Richard A et al. (2012): Induction of heat shock proteins by hyperthermia and noise overstimulation in HSF1. Mice; JARO 13: 29-37.

11. Hassan MA, Hosny MA and Soliman EF (2010): Occupational hearing loss due to noise exposure and its relation with heat shock protein 70 and its antibody. Med J Cairo Univ; 78 (1): 511-16.

12. Ho K, Wang H, Tsai S, Chung L, Wu Y et al. (2012): Evaluation and clinical significance of serum heat shock protein70, 60 and 27 on hearing recovery in patients with idiopathic unilateral sudden hearing loss. Int Adv Otol; 8:(2) 171-78.

13. Huilin Y, Cheng Q and Yi L (2004): Study on the relationship between antibody against heat shock protein 60 and ECG abnormal in the workers exposed to noise. CNKI Journal Chinese General Practice; 14: 1-10.

14. Itoh H, Komatsuda A, Ohtani H, Wakui H, Imai $\mathrm{H}$ et al. (2002): Mammalian HSP60 is quickly sorted into the mitochondria under conditions of dehydration. Eur J Biochem; 269 (23): 5931-8.

15. Lewthwaite J, Owen N, Coates A, Henderson B and Steptoe A (2002): Circulating human heat shock protein 60 in the plasma of British civil servants: relationship to physiological and psychosocial stress. Circulation; 106: 196-201.

16. Macario AJL, Cappello F, Zummo G, Conway de Macario E (2010): Chaperonopathies of senescence and the scrambling of interactions between the chaperoning and the immune systems. Ann N Y Acad Sci; 1197: 85-93.

17. Mandal K, Jahangiri M and Xu Q (2004): Autoimmunity to heat shock proteins in atherosclerosis. Autoimmun Rev; 3: 31-7.

18. Osiris W, Mohamed A and Hany S (2014): The association between noise exposure and blood pressure and ECG of workers in Egyptian factories. The 21st International Congress on Sound and Vibration (ICSV 21), Beijing, China, 13-17 July 2014.

19. Rea IM, McNerlan S and Pockley AG (2001): Serum heat shock protein and anti-heat 
shock protein antibody levels in aging. Exp Gerontol; 36: 341-52.

20. Rizzo M, Macario AJL, Conway de Macario E, Gouni-Berthold I, Berthold H et al. (2011): Heat shock protein-60 and risk for cardiovascular disease. Current Pharmaceutical Design; 17, 3662-68.

21. Rossi MR, Somji S, Garrett SH, Sens MA, Nath J et al. ( 2002): Expression of hsp 27, hsp 60, hsc 70 , and hsp 70 stress response genes in cultured human urothelial cells (UROtsa) exposed to lethal and sublethal concentrations of sodium arsenite. Environ Health Perspect; 110: 122532.

22. Shamaei-Tousi A, Steptoe A, O'Donnell K, Palmen J, Stephens JW et al. (2007): Plasma heat shock protein 60 and cardiovascular disease risk: the role of psychosocial, genetic and biological factors. Cell stress \& Chaperones; 12(4): 384-92.

23. Toppila E, Pyykko Ilmari and Starck J (2001): Age and noise-induced hearing loss. Scand Audiol; 30(4): 236-44.
24. Vargas-Parada L and Solis C (2001): Heat Shock and stress response of Taenia solium and $\mathrm{T}$. crassiceps. Parasitology; 122: 583-8.

25. Yang M, Zheng J, Yang Q, Yao H, Chen Y et al. (2004): Frequency-specific association of antibodies against heat shock protein 60 and 70 with noise-induced hearing loss in Chinese workers. Cell Stress \& Chaperones; 9 (2): 207-13.

26. Yang M, Tan H, Yang Q, Wang F, Yao H et al. (2006): Association of hsp70 polymorphisms with risk of noise-induced hearing loss in Chinese automobile workers. Cell Stress \& Chaperones; 11(3):233-39.

27. Yuan J, Yang M, Yao H, Zheng J, Yang Q et al. (2005): Plasma antibodies to heat shock protein 60 and heat shock protein 70 are associated with increased risk of electrocardiograph abnormalities in automobile workers exposed to noise. Cell Stress \& Chaperones; 10 (2): 126-35.

28. Zhang X, He M, Cheng L, Chen Y, Zhou L et al. (2008): Elevated heat shock protein 60 levels are associated with higher risk of coronary heart disease in Chinese. Circulation; 118: 2687-93. 